\title{
Remédios para a tristeza: as instruçóes religiosas de Francisco de Sales em Introdução à vida devota, Portugal (séculos XVII-XVIII)
}

\author{
Eliane Cristina Deckmann Fleck ${ }^{1 *}$ \\ ${ }^{1}$ Universidade do Vale do Rio dos Sinos, Rio Grande do Sul, Brasil
}

Mauro Dillmann ${ }^{2 * *}$

${ }^{2}$ Universidade Federal de Pelotas, Rio Grande do Sul, Brasil

\section{RESUMO}

Este texto analisa as instruçóes morais e religiosas do doutor em Teologia e bispo francês Francisco de Sales (1567-1622) em sua obra Introdução à vida devota [1609], especialmente em relação ao sentimento da tristeza. Atenta-se para os significados da tristeza, os seus efeitos "bons" e "ruins" e os "remédios" apresentados para combatê-la, bem como para os sentidos médicos e filosóficos compartilhados à época - que acionavam a teoria humoral para compreender os motivos e os efeitos da melancolia —, notadamente a partir do contexto português dos séculos XVII e XVIII, período de ampliação da leitura de obras de espiritualidade em Portugal, bem como de difusão da obra salesiana.

Palavras-chave: Francisco de Sales; tristeza; melancolia; leitura; Portugal.

DOI: http://dx.doi.org/10.1590/2237-101X02004103

Artigo recebido em 20 de fevereiro de 2018 e aceito para publicação em 15 de junho de 2018.

* Professora da Universidade do Vale do Rio dos Sinos/Departamento de História, Programa de Pós-graduação em História, São Leopoldo/RS — Brasil. E-mail: ecdfleck@terra.com.br. ORCID: http://orcid. org/0000-0002-7525-3606.

** Professor da Universidade Federal de Pelotas/Instituto de Ciências Humanas, Departamento de História, Programa de Pós-graduação em História, Pelotas/RS - Brasil. E-mail: maurodillmann@hotmail.com. ORCID: https://orcid.org/0000-0002-8315-7788.

Este artigo é resultado de pesquisas realizadas por ambos os pesquisadores no âmbito do projeto Tende sempre convosco algum bom livro de devoção: discursos morais, devoção e vida virtuosa na literatura religiosa lusoamericana, séculos XVI-XVIII, que conta com financiamento da FAPERGS e do CNPq, e é coordenado por Mauro Dillmann (UFPEL). 


\section{Remedies for sadness: the religious instructions of Francisco de Sales in Introduçâo à vida devota, Portugal (17th-18th centuries)}

\section{ABSTRACT}

This text analyses the moral and religious instructions from Doctor in Theology and French Bishop Francisco de Sales (1567-1622) in his work 'Introdução à vida devota' [1609], particularly in its relation to the feeling of sadness. We detain ourselves over the meanings of sadness, its "good" and "bad" effects and the "remedies" presented to combat it, as well as the medical and philosophical meanings shared at the time - which used humorism to understand the reasons and effects of melancholy — - especially in the Portuguese context of the 17th and 18th centuries, a period of increase of the reading of works of a spiritual nature in Portugal, as well as a period of diffusion of Salesian works.

Keywords: Francisco de Sales; sadness; melancholy; reading; Portugal.

\section{Remedios para la tristeza: las instrucciones religiosas de Francisco de Sales en Introduçâo à vida devota, Portugal (Siglos XVII-XVIII)}

\section{RESUMEN}

Este texto analiza las instrucciones morales y religiosas del doctor en Teología y Obispo francés Francisco de Sales (1567-1622) en su obra Introdução à vida devota [1609], especialmente en relación al sentimiento de tristeza. Teniendo en cuenta los significados de la tristeza, sus efectos "buenos" y "malos" y los "remedios" mostrados para combatirla, así como para los sentidos médicos y filosóficos compartidos en la época — que accionaban la teoría humoral para comprender los motivos y los efectos de la melancolía-, especialmente a partir del contexto portugués de los siglos XVII y XVIII, periodo de ampliación de la lectura de obras de espiritualidad en Portugal, así como de difusión de la obra salesiana.

Palabras clave: Francisco de Sales; tristeza; melancolía; lectura; Portugal.

\section{Introdução}

O espírito da Reforma católica em Portugal foi marcado, entre outros aspectos, pelo caráter pedagógico dos agentes religiosos e pelas diferentes modalidades de comunicação para a difusão dos discursos católicos pelo império português. ${ }^{1}$ Para além das açôes punitivas da

${ }^{1}$ PALOMO, Federico. A Contra-Reforma em Portugal, 1540-1700. Lisboa: Livros Horizonte, 2006. p. 57-58. 
Igreja católica, os esforços pós-tridentinos foram reforçados pela produção de uma literatura de caráter espiritual, destinada a membros do clero, aos párocos e aos leigos em geral, que atendia os objetivos de orientação religiosa e visava à interiorização de práticas, emoçóes e condutas. $^{2}$ Este foi um período, segundo João Marques, ${ }^{3}$ "propiciador de vocaçóes religiosas e itinerários de santidade [...] tempo em que 'todos queriam, ser santos"', pois nos séculos XVI e XVII havia "atmosferas de fervoroso interesse das pessoas pelos exercícios de alta espiritualidade". ${ }^{4}$ Desse modo, segundo Marques, diversos mecanismos, tais como imagens, celebraçôes litúrgicas e pregaçôes, buscavam estimular a devoção dos fiéis. A difusão da fé cristã e da devoção passava pela "renovação da prática sacramental e da espiritualidade”, pela evangelização intensa e pela mudança nas expressóes de sentimentos e fé. 5

Francisco de Sales (1567-1622), doutor em Direito e Teologia e bispo de Annecy, a partir de 1602, foi um dos maiores representantes da "escola francesa de espiritualidade" do século XVII, tendo contribuído para que "a mística saí[sse] dos mosteiros" e seguisse em "direção ao mundo", atingindo soldados, artesãos, príncipes e o lar das pessoas comuns que teriam expectativas de atingir a perfeição "que antes parecia reservada aos clérigos". ${ }^{6}$ Assim, as liçóes de Sales contribuíram "para reforçar no seio do catolicismo romano a existência de uma corrente que enaltece como a suprema perfeição a união pessoal da alma com Deus neste mundo". 7 Desse modo, Sales

[...] mostra que o cumprimento do dever pode ser um meio tão eficaz quanto a oração e a contemplação para aceder a essa vida perfeita e à mais elevada espiritualidade. Também desenvolve a ideia de que a devoção e até o misticismo não constituem setores à parte, momentos privilegiados, porém devem irrigar a vida de todo dia [...]. Assim, corresponde à expectativa de muitos cristãos que $[. .$.$] não anelam menos por uma perfeição que antes parecia reservada aos clérigos. { }^{8}$

Defensor da oração, contemplação, devoção e misticismo, Francisco de Sales foi um famoso diretor espiritual, ${ }^{9}$ beatificado em 1661, durante o pontificado do papa Alexandre VII,

\footnotetext{
${ }^{2}$ Ibidem, p. 57.

${ }^{3}$ MARQUES, João Francisco. Oração e devoçôes. In: AZEVEDO, Carlos Moreira (Dir.). História da vida religiosa de Portugal. Humanismos e reformas. Lisboa: Círculo de Leitores, 2000. p. 645. v. 2.

${ }^{4}$ BORGES, Célia Maia. Livros de devoção e exercícios oracionais no Brasil Colônia: a biblioteca das Carmelitas Descalças no Rio de Janeiro. Séc. XVIII. In: FLECK, Eliane Cristina Deckmann; DILLMANN, Mauro (Orgs.). Escritas e leituras: temas, fontes e objetos na Iberoamérica, séculos XVI-XIX. São Leopoldo: Oikos; Unisinos, 2017. p. 165.

${ }^{5}$ Idem.

${ }^{6}$ LEBRUN, François. As reformas: devoçôes comunitárias e piedade pessoal. In: CHARTIER, Roger (Org.). História da vida privada, 3: da Renascença ao Século das Luzes. Trad. Hildegard Feist. São Paulo: Companhia das Letras, 2009. p. 104.

${ }^{7}$ Idem.

${ }^{8}$ Ibidem, p. 103.

${ }^{9}$ DAWSON, Christopher. A divisão da cristandade. Da Reforma Protestante à Era do Iluminismo. Trad. Márcia de Brito. São Paulo: É Realizações, 2014. p. 223.
} 
e, logo depois, canonizado. $\mathrm{O}$ historiador João Marques se refere ao religioso como

[...] catequista, apologeta, pregador, autor ascético da clássica Introdução à vida devota, canonizado em 1665, diretor espiritual e amigo de Santa Joana-Francisca Frémiot de Chantal (1572-1641), a quem ajudou a fundar a Ordem da Visitação, destinada a mulheres e viúvas que não podiam suportar as austeridades das congregaçōes mais antigas. ${ }^{10}$

A principal obra de Sales, tão logo publicada em 1609, ganhou inúmeras traduçôes, sendo editada e reeditada constantemente nos séculos XVII e XVIII. Dedicado à "Filoteia", à alma amante de Deus, o livro traz uma série de instruçóes sobre a consolidação de uma vida devota, longe dos vícios, das tentaçóes e do pecado, além de conselhos, exercícios e avisos para a condução da alma na prática dos bons pensamentos, da meditação e da oração. Apenas na França, entre os anos 1620 e 1670, a obra de Sales contou com mais de trinta edições, ${ }^{11}$ e, em Portugal, contou com duas edições no século XVII (1682 e 1685) e quatro no século XVIII (1729, 1758, 1765 e 1784).

Em geral, obras de caráter religioso figuravam fortemente nos repositórios privados portugueses $^{12}$ do século XVIII e, entre esses acervos, estava o livro Introdução à vida devota. ${ }^{13}$ Além disso, o jornal Gazeta de Lisboa anunciava, entre 1727 e 1758, continuamente, a divulgação do "livro de ouro" e outras obras de Sales, destacando os locais em que os exemplares eram comercializados, tais como lojas, a exemplo de "Bonardel Beux, mercadores de livros", ${ }^{14}$ portas de igrejas, conventos e congregaçóes, além das próprias casas dos livreiros, que eram identificados pelos nomes, como Luis António Alfeirão, Miguel Rodrigues, e, ainda, nas oficinas, como na de Pedro Ferreira "ao arco de Jesus junto a S. Nicolau".

${ }^{10}$ MARQUES, João Francisco. Oração e devoções, op. cit., p. 647.

${ }^{11}$ COSTA, Manuel Afonso. A ideia de felicidade em Portugal no século XVIII, entre as luzes e o romantismo. Eticidade, moralidade e transcendência. Tese (Doutorado em História e Teoria das Ideias) — Universidade Nova de Lisboa, 2008. p. 8.

${ }^{12}$ Entre os séculos XVI e XVIII, segundo António Barros Cardoso, “o livro torna-se um objeto mais presente na intimidade da residência e o número dos que possuem pequenas bibliotecas é evidenciado sobretudo através dos inventários pós-morte onde [...] se descrevem os livros que o indivíduo legou”. CARDOSO, António Barros. Livrarias e bibliotecas na Europa dos tempos modernos. The Overarching Issues of the Europen Space. Ed. Faculdade de Letras da Universidade do Porto, p. 361-373, 2013. p. 364. Roger Chartier já havia destacado a "familiarização com o livro de propriedade pessoal na privacidade do lar" e o "aumento da porcentagem dos possuidores de bibliotecas" em diversos estados europeus, situaçóes que apontam para o processo de privatização (posse privada de livros) ao longo do século XVIII. CHARTIER, Roger. As práticas da escrita. In: CHARTIER, Roger (Org.). História da vida privada, 3: da Renascença ao Século das Luzes. Trad. Hildegard Feist. São Paulo: Companhia das Letras, 2009, p. 113-162, p. 132.

${ }^{13}$ ARAÚJO, Ana Cristina. A morte em Lisboa: atitudes e representaçôes, 1700-1830. Lisboa: Editorial Notícias, 1997, p. 31.

${ }_{14}$ Gazeta de Lisboa, 12 outubro 1758. Disponível em: repositorio.ul.pt/bitstream/10451/358/5/22491_ ulfl062037_tm_vol_2.pdf. Acesso em: 6 jan. 2018.

${ }_{15}$ Gazeta de Lisboa, 18 dezembro 1727. Disponível em: repositorio.ul.pt/bitstream/10451/358/5/22491_ ulfl062037_tm_vol_2.pdf. Acesso em: 6 jan. 2018. 
Em Lisboa, o livro foi publicado nas oficinas tipográficas de Miguel Menescal, Domingues Gonçalves, Antonio Vicente da Silva e de Francisco Luiz Ameno, e, em Coimbra, na oficina de Antonio Simoens Ferreira. Entre os acervos em que suas obras podiam ser encontradas estáo a Ordem dos Frades Menores do Convento de São Francisco de Lisboa, o Colégio de São Pedro de Coimbra e o Colégio dos Cônegos Seculares de São João Evangelista de Coimbra.

Como se pode constatar, a obra de Sales assumiu inequívoca importância no universo de leituras católicas em Portugal, ${ }^{16}$ no âmbito de difusão de máximas católicas reformistas, e, durante todo o século XVIII, os textos salesianos se tornaram um "modelo a seguir" em várias partes da Europa, sendo traduzidos para diferentes idiomas. ${ }^{17}$ As ideias de Sales se traduziam nos diversos "avisos" contra as tentaçóes a que os sujeitos cristãos estariam suscetíveis, como se observa no livro Introdução à vida devota, que consistia de instruçóes aos fiéis/leitores em relação à tristeza, ao desassossego e aos pecados.

Neste artigo, além de destacar a percepção de Francisco de Sales sobre a tristeza, apresentamos e discutimos as instruçóes dadas aos potenciais leitores, em especial, os "remédios" e as formas indicadas para combater esse sentimento, também encarado como doença pela medicina da época.

Considerando a ampliação das práticas de escrita e leitura ao longo do período moderno, a análise da percepção em relação ao sentimento de tristeza, seus efeitos e seus remédios, expressos em Introdução à vida devota, levará em conta, sempre que possível, sua compreensão para a sociedade católica portuguesa dos séculos XVII e XVIII, e, também, aquela que vigorava na Europa ocidental moderna. ${ }^{18}$ Vale, ainda, lembrar que, apesar do sucesso editorial do

\footnotetext{
${ }^{16}$ Entre outras leituras de espiritualidade produzidas ou traduzidas em Portugal, e que tiveram sucesso editorial entre os séculos XVII e XVIII, destacam-se obras de Luís de Granada, de Manuel Bernardes, de João Franco, de Lorenzo Scupoli, de Afonso Rodrigues e do próprio Francisco de Sales, entre outros. Ver mais em: CARVALHO, José Adriano de Freitas. Do recomendado ao lido. Direcção espiritual e prática de leitura entre franciscanas e clarissas em Portugal no século XVII. Via Spiritus, v. 4, p. 7-56, 1997, e CARVALHO, José Adriano de Freitas (Dir.). Bibliografia cronológica da literatura de espiritualidade em Portugal. 1501-1700. Faculdade de Letras da Universidade do Porto. Porto: Instituto de Cultura Portuguesa, 1988. Disponível em: https://repositorio-aberto.up.pt/handle/10216/7014.

${ }^{17}$ SANTOS, Zulmira. Vícios, virtudes e paixóes: da novela como "catecismo" no século XVIII. Revista de Estudos Ibéricos, Porto, n. 3, p. 187-199, 2006. p. 199.

${ }^{18}$ Segundo Roger Chartier, "em toda a Europa esclarecida [...] profundas mudanças transformam a produção impressa e as condiçóes de acesso ao livro. Em todos os lugares, o crescimento [...] da oferta impressa, a circulação de livros interditos, a multiplicação dos periódicos, o triunfo dos pequenos formatos e a proliferação dos gabinetes literários e sociedades de leitura [...] permitem e impóem novas maneiras de ler”. Assim, a leitura poderia ocorrer de diferentes formas e os textos poderiam ser tanto lidos, relidos e memorizados, como lidos rapidamente e logo descartados" (CHARTIER, Roger. Inscrever e apagar: cultura escrita e literatura, séculos XI-XVIII. Trad. Luzmara Ferreira. São Paulo: Unesp, 2007. p. 265-266). Para Portugal, Palomo demonstrou que os estudos sobre bibliotecas confirmam a "presença avultada de obras religiosas"; as elites eclesiásticas e laicas (nobres) da época encontravam, nas grandes coleçôes de livros, prestígio social e cultural. Obras de oração e meditação, instruçóes para vida devota, catecismos, tratados de teologia e textos litúrgicos são alguns exemplos dos conteúdos das bibliotecas. A apropriação desse conteúdo passada pela leitura silenciosa, de modo a aprender e interiorizar condutas, mas também, muitas vezes, em voz alta, uma prática comum nos ambientes eruditos da época. PALOMO, Federico. A Contra-Reforma em Portugal, op. cit., p. 62-63.
} 
título e de suas ediçóes, "a injunção nem sempre acarreta obediência", ${ }^{19}$ razão pela qual seria por demais arriscado afirmar que os "remédios" para a tristeza equivaliam — sem qualquer desvio - à maneira como os sujeitos católicos pensavam ou experienciavam esse sentimento nos contextos e espaços em que a obra circulou e foi lida. ${ }^{20}$ Isto, no entanto, não invalida perceber as normas enunciadas e os "remédios" propostos por Sales, que pretendia regrar e combater a tristeza, como expressão também da percepção dos leitores católicos portugueses e dos segmentos intelectuais que refletiam sobre a melancolia à época.

Priorizaremos, em razão disso, a análise do discurso religioso sobre a expressão e os efeitos do sentimento de tristeza que procurou orientar os fiéis-leitores aos modos de viver religiosa e devotamente, livrando-os da tristeza a partir da prescrição de remédios para a alma cristá. Trata-se, por outro lado, de considerar, também, a importância que a prática da leitura assumiu como meio instrutivo para adoção ou modificação de condutas, especialmente a partir do crescimento editorial da literatura devota entre o final do Seiscentos e o início do Setecentos, em Portugal. É preciso dizer que confessores e diretores espirituais acreditavam fortemente que a leitura de livros de espiritualidade - missais, breviários, sumas teológicas, livros de confissão, peças teatrais jesuítas, vidas de santos, autobiografias de santas, novelas devotas, sermóes e textos classificados como "espirituais" 21 — implicavam na mudança de comportamentos, determinando a aquisição e conservação de virtudes morais cristãs.

Embora saibamos que a segunda metade do século XVII seja um "dos momentos altos da invasão salesiana na península [Ibérica]" 22 — o que leva a crer na possibilidade de as obras de Sales não serem apenas lidas, mas, também, recomendadas e aconselhadas para outros leitores — não podemos precisar a eficácia, ou não, da interiorização de certas práticas pela leitura da obra de Sales, motivo pelo qual, reiteramos, nos propusemos a analisar primordialmente os discursos sobre a tristeza e a indicação de seus "remédios".

\footnotetext{
${ }^{19}$ CHARTIER, Roger. Leituras e leitores na França do Antigo Regime. Trad. Álvaro Lorencini. São Paulo: Unesp, 2004. p. 172.

${ }^{20}$ Como não dispomos de qualquer evidência de leitura da obra, como por exemplo narrativas autobiográficas, correspondências, diários (CHARTIER, Roger (Dir.). Práticas da leitura. Trad. Cristiane Nascimento. 5. ed. São Paulo: Estaçáo Liberdade, 2011. p. 21), não temos intenção de fazer nenhuma referência a supostas recepçôes da obra de Sales. No entanto, sabemos que as possibilidades de leitura são também possibilidades a partir de situaçóes nas quais se lê e nas "condições sociais de produção de leitores" (BOURDIEU apud CHARTIER, Roger. Inscrever e apagar, op. cit., p. 267). Em Portugal, a obra de Sales circulou em conventos e colégios religiosos, o que implica perceber que determinadas modalidades particulares de leitura e práticas próprias da comunidade de leitores religiosos determinavam o entendimento do texto e as maneiras de ler. ${ }^{21}$ CARVALHO, José Adriano de Freitas. Lectura espiritual en la peninsula ibérica (siglos XVI-XVII): programas, recomendaciones, lectores, tiempos y lugares. Salamanca: Editorial Semyr, 2007. p. 12.

${ }^{22}$ Ibidem, p. 50.
} 


\section{A tristeza e seus efeitos}

Reflexôes religiosas, literárias, filosóficas e médicas sobre a tristeza e a melancolia entendidas como sinônimos, como veremos mais adiante - ocuparam parte do interesse dos letrados, dos leitores e dos impressores da Península Ibérica no período moderno. Jean Delumeau, ${ }^{23}$ referindo-se ao período entre o final do século XV e o século XVII, destacou que "toda uma época [...] interrogou-se sobre a natureza e as consequências da tristeza, desde os inquisidores até os médicos, passando pelos filósofos, artistas e poetas". No século XVI, o médico espanhol Andrés Velázquez publicava o Libro de la melancholia: en el qual se trata de la naturaleza desta enfermedad, assi llamada Melancholia, y de sus causas y simptomas, ${ }^{24}$ [1585]. Outro médico e filósofo espanhol, Juan Huarte de San Juan (1529-1588), em sua obra Examen de Ingenios para las ciências, publicada inúmeras vezes entre os séculos XVII e XVIII, ${ }^{25}$ teria, segundo Tausiet e Amelang, ${ }^{26}$ obtido grande fama com suas ponderações sobre a fisiologia de sentimentos como a melancolia. Em Portugal, possivelmente, também circulou a obra Disputationes medicae... ${ }^{27}$ de Pedro García Carrero (1555-1630), que dedica três capítulos aos melancólicos. ${ }^{28}$ Alonso de Santa Cruz redige, antes de 1613, um De melancholia, e o médico André du Laurens, com Discurso da conservação da vida; doenças melancólicas; dos catarros e da velhice (1597), alcança inúmeras edições francesas e diversas traduçóes até 1626. ${ }^{29}$ Outro sucesso foi o tratado de Robert Burton, A anatomia da melancolia, "publicado e disputado pelos leitores ingleses: cinco ediçōes saem durante a vida do autor que morre em 1640". ${ }^{30}$

Além da ciência médica, a literatura tratou da tristeza, como se observa na novela Alivio de tristes, consolo de queixosos, do padre português Matheo Ribeyro, que ganhou diferentes ediçôes nos anos de 1648, 1672, 1688, 1734, 1737, 1754, 1755, 1757 e 1764. ${ }^{31}$ Segundo Manuel Costa, "a poesia portuguesa do século XVIII está [...] cheia de 'horrores', 'tristezas', ou expressóes como 'Que triste horror', 'triste até morrer' [...] em poetas como Domingos Caldas Barbosa, Maximinao Torres, João Xavier de Matos, Bocage, Filinto Elíseo, Paulino António Cabral, etc." Também no século XVIII, a obra religiosa do eclesiástico Juan Jove

\footnotetext{
${ }^{23}$ DELUMEAU, Jean. O pecado e o medo. A culpabilização no Ocidente (séculos 13-18). Trad. Álvaro Lorencini. Bauru: Edusc, 2003. v. 1. p. 321.

${ }^{24}$ A Biblioteca Nacional da Espanha guarda seis exemplares: http://catalogo.bne.es.

${ }^{25}$ Ver catálogos da BNP e BNE, http://catalogo.bnportugal.pt e http://catalogo.bne.es.

${ }^{26}$ TAUSIET, María; AMELANG, James S. (Orgs.). Accidentes del alma: las emociones en la Edad Moderna. Madrid: Abada Editores, 2009, p. 24.

${ }^{27}$ A BNP guarda dois exemplares publicados na Espanha; um de 1605, impresso pela "ex officina Justi Sanchez Crespo", e outro de 1611, impresso pela "ex officina Joannis Gratiani".

${ }^{28}$ OROBITG, Christine. El sistema de las emociones: la melancolía en el Siglo de Oro Español. In: TAUSIET, María; AMELANG, James S. (Orgs). Accidentes del alma, op. cit., p. 92.

${ }^{29}$ DELUMEAU, Jean. O pecado e o medo, op. cit., p. 321.

${ }^{30}$ Ibidem, p. 322.

${ }^{31}$ Ver em https://novelisticabarrocaportuguesa.wordpress.com/alivio-de-tristes-e-consolacao-de-queixosos-1764/.
} 
y Muñiz (?-1775), doutor teólogo da Universidade de Oviedo, na Espanha, apresentava no título de sua obra as "receitas contra toda tristeza". ${ }^{32} \mathrm{O}$ mesmo pode ser observado na obra Desterro da melancolia, e consolação, e alivio para todos os que são melancólicos viverem alegres, e conformes com a vontade de Deus, sem indicação de autoria, que foi publicado em 1769. Como ressaltado por Orobitg, ${ }^{33}$ os discursos filosóficos, médicos, religiosos e literários que versavam sobre os mais variados sentimentos trazem evidências de sua circulação e interinfluência, na medida em que médicos citavam a Bíblia e clérigos citavam médicos, poetas e filósofos, ao lidarem com emoçôes e paixôes, e, dentre elas, a melancolia e a tristeza. ${ }^{34}$

A historiografia e outras áreas com interesses em historicizar seus objetos de estudo também se voltam para a análise e compreensão dos sentimentos de tristeza e melancolia. ${ }^{35}$ Delumeau dedicou muitas páginas do livro $O$ pecado e o medo ao estudo da melancolia na mentalidade coletiva do ocidente moderno europeu, um contexto marcado pelos discursos com premissas culpabilizantes. Roger Bartra, no seu livro Cultura y melancolia. Las enfermidades del alma en la España del Siglo de Oro, analisa diferentes textos e interpretaçôes dos séculos XVI e XVII sobre a melancolia, cruzando entendimentos religiosos e científicos para demonstrar o impacto dessa "enfermidade" na cultura moderna espanhola. A já citada Christine Orobitg estudou a melancolia no sistema de emoçôes e paixôes durante o Século de Ouro espanhol, atentando para os processos orgânicos que vinculavam corpo e alma a partir do equilíbrio ou desequilíbrio de humores e dos movimentos do coração.

O historiador da medicina e crítico literário Jean Starobinsky, por sua vez, interrogou-se sobre a história do tratamento da melancolia e da própria doença, atento às condiçôes culturais que determinaram ou interferiram nas narrativas que visavam à compreensão do fenômeno. Na história da arte, destaca-se o trabalho de Klibansky, Panofsky e Saxl, Saturno y la melancolia, um grande estudo dedicado às transformaçóes da noção de melancolia da Antiguidade ao período medieval, cujo título remete a Saturno, o "astro da melancolia" nas tradiçóes literárias e pictóricas.

No Século de Ouro espanhol, a construção cultural dos discursos sobre paixôes estava baseada na teoria humoral, ${ }^{36}$ concebida a partir da crença na existência de quatro humores

\footnotetext{
${ }^{32}$ Jovial christiano, y erudito, no menos util, que gustosamente entretenido: Democrito nuevo, contento en toda fortuna, arte de vivir alegre, y de reirse del mundo, consuelo en todo genero de aflicciones, y recetas contra toda tristeza [1753].

${ }^{33}$ OROBITG, Christine. El sistema de las emociones, op. cit., p. 73.

${ }^{34}$ Esses e outros discursos sobre a tristeza circulavam em Portugal no mesmo período em que a obra de Sales ganhava suas reediçóes, motivo pelo qual os referenciamos, na medida em que permitem compreender o contexto de construção social da expressão desse sentimento e perceber a importância e as diferentes abordagens que a tristeza merecia à época.

${ }^{35}$ Veja-se BARTRA, Roger. Cultura y melancolia. Las enfermidades del alma en la España del Siglo de Oro. Barcelona: Anagrama, 2001. Uma abordagem filosófica e histórica, STAROBINSKI, Jean. A tinta da melancolia. Uma história cultural da tristeza. Trad. Rosa Freire D’Aguiar. São Paulo: Companhia das Letras, 2016. ${ }^{36}$ Também conhecida como teoria hipocrático-galênica, defende que a vida era mantida pelo equilíbrio entre quatro humores: sangue, fleuma, bílis amarela e bílis negra, procedentes, respectivamente, do sistema respi-
} 
que deviam estar em equilíbrio para assegurar uma vida saudável. Na obra De humana physiognomia — livro difundido na Espanha entre os séculos XVI e XVIII —, Giambattista della Porta defendia que "os que são de humor melancólico são chamados tristes porque seus espíritos são afligidos por uns escuros vapores". ${ }^{37} \mathrm{O}$ humor melancólico seria atraído "pelo baço, órgão de cor escura que se supóe ser o centro da bile negra”; ${ }^{38}$ tal humor, segundo o médico Ambroise Paré (1510-1590) "é feito com alimentos de suco grosso e difíceis de cozinhar, e também de contrariedades e desgostos de espírito" ${ }^{39} \mathrm{O}$ órgão facilmente ativado pela tristeza era o olho, pois os olhos agitavam toda a tristeza quando "se via a vida fundamentalmente como um vale de lágrimas”. ${ }^{40}$

O filósofo René Descartes (1596-1650) definia tristeza como "uma languidez desagradável, que consiste no mal-estar que a alma recebe do mal ou da falta que as impressóes do cérebro lhe representam como lhe pertencentes a ela", cuja causa estaria na "nossa opinião de ter algum mal ou alguma falta”, fosse em relação ao corpo ou em relação à alma. ${ }^{41}$ Essa ideia de que "os sintomas melancólicos eram o resultado de uma agressão do cérebro" 42 chega ao século XVIII, somada às responsabilidades atribuídas ao sistema nervoso, sendo que a melancolia era tida como "uma doença do ser sensível". 43

Na obra de Sales, o sentimento de tristeza é tratado no capítulo doze — "Da tristeza" — da quarta parte do livro, dedicada aos "avisos” que seriam "necessários contra as tentações mais ordinárias". " $\mathrm{Na}$ edição que utilizamos neste artigo, tal instrução ocupa pouco mais de quatro páginas de um total de 614 páginas que compóem a obra. No prefácio, o autor destaca que um dos objetivos deste capítulo era possibilitar que o leitor "descobri[sse] algumas emboscadas de seus inimigos" (geralmente demônios), mostrando "como deve desembaraçar-se deles e continuar na sua empresa". ${ }^{45}$ A tristeza seria essa ameaça associada aos artifícios dos inimigos e a instrução dada por Sales era que fossem descobertas "para, então, garantir o "desembaraçamento". Em outras palavras, a tristeza decorria da ação de um Outro, um inimigo, sendo que a ameaça externa devia ser localizada e identificada para,

ratório, fígado e baço. Cada um desses humores teria diferentes qualidades: o sangue seria quente e úmido; a fleuma, fria e úmida; a bílis amarela, quente e seca; e a bílis negra, fria e seca.

${ }^{37}$ OROBITG, Christine. El sistema de las emociones, op. cit., p. 77. Tradução livre.

${ }^{38}$ DELUMEAU, Jean. O pecado e o medo, op. cit., p. 323.

${ }^{39}$ Ibidem, p. 326.

${ }^{40}$ RUBLACK, Ulinka. Flujos. El cuerpo y las emociones en la Edad Moderna. In: TAUSIET, María; AMELANG, James S. (Orgs.). Accidentes del alma, op. cit., p. 109. Tradução livre.

${ }^{41}$ DESCARTES, René. As paixóes da alma. Introdução, notas, bibliografia e cronologia por Pascale D’Arcy. Trad. Rosemary Costhek Abílio. 2. ed. São Paulo: Martins Fontes, 2005 [1649], p. 91-92.

${ }^{42}$ STAROBINSKI, Jean. A tinta da melancolia, op. cit., p. 65.

${ }^{43}$ Ibidem, p. 66.

${ }^{4}$ SALES, Francisco de. Introdução à vida devota. Nova edição revista e prefaciada com prólogo do padre Gonçalo Alves. Porto: Livraria Catholica Portuense, Centro de Propaganda religiosa em Portugal e Brazil, s/d [1609], p. 418.

${ }^{45}$ Ibidem, p. 26. 
dessa forma, garantir uma espécie de libertação. Logo, num primeiro momento, a tristeza ganhava atributo negativo, cuja "culpa” estava na exterioridade, e não no cultivo individual, subjetivo e interior: "O inimigo folga com a tristeza e melancolia, porque como ele é triste e melancólico e o será eternamente, deseja que todos sejam como ele”. ${ }^{4}$

Todavia, na reflexão de Sales, a tristeza se apresenta como uma paixão, uma inclinação da alma para os aspectos materiais e corporais da existência - e não tanto aos bens espirituais - que facilmente poderia conduzir ao pecado, embora pudesse conter aspectos positivos. Sales estava, muito provavelmente, inspirado em Tomás de Aquino (1225-1274), para quem paixão é "algo que acontece com uma pessoa, algo que aquela pessoa precisa sofrer e com relação à qual ele ou ela é passivo”. ${ }^{47}$ A tristeza, juntamente com o ódio e a negação, seria uma das partes negativas das paixóes concupiscentes, aquelas que "respondem ao que nós percebemos serem coisas boas ou ruins, coisas que nos atraem ou nos repelem" ${ }^{48}$ Para o moralista, teólogo e filósofo francês Pierre Charron (1541-1603), em Da sabedoria [1601], ${ }^{49}$ a tristeza estaria ao lado "do ciúme, da crueldade e do temor", uma paixão infame que "amargura nossa vida e envenena todas as nossas açóes", sendo "a mais desagradável, prejudicial e injusta paixão" 50

Sales apresenta-nos a tristeza como um sentimento capaz de fabricar ou "obrar" o bem ou o mal, dependendo de sua constituição e dos seus efeitos, uma vez que aquela que existia "segundo Deus" obraria a "penitência para a salvação", enquanto aquela que seria "do mundo" obraria "a morte". Sob essa interpretação, a tristeza vinda de Deus se constituía enquanto salvação, e a tristeza vinda do mundo, enquanto morte. Esse caráter ambíguo da tristeza também estava presente na filosofia moderna, segundo Orobitg, ${ }^{1}$ "como paixão, cega o entendimento, perturba a alma e corrompe o juízo, mas, por favorecer o reconhecimento e a reflexão, também constitui uma possível via até a sabedoria”.

A tristeza, para Sales, portava características muito mais negativas do que positivas, produzindo, na frágil vida humana, muitos mais efeitos "maus" do que "bons". Os efeitos bons da tristeza eram apenas dois, a compaixão e a penitência; enquanto seis eram os efeitos maus, a angústia, a preguiça, a indignação, o zelo, a inveja e a impaciência. Segundo Delumeau, no século XVI, a tristeza era "comum à preguiça”, que afligia pessoas que "caminham lentamente", "de cabeça baixa" e com excesso de sono. ${ }^{52}$ A impaciência e a inquietude eram perturbaçóes melancólicas de "almas demasiado inquietas [que] chegavam a duvidar do perdão divino e até

\footnotetext{
${ }^{46}$ Ibidem, p. 457.

${ }^{47}$ POTKAY, Adam. A história da alegria. Da Bíblia ao Romantismo tardio. São Paulo: Globo, 2010. p. 36.

${ }^{48}$ Idem.

${ }^{49}$ A BNP guarda um exemplar de 1606, um de 1656 e três de 1782, todos em francês, com o título original

"De la sagesse".

${ }^{50}$ DELUMEAU, Jean. O pecado e o medo, op. cit., p. 339.

${ }^{51}$ OROBITG, Christine. El sistema de las emociones, op. cit., p. 86. Tradução livre.

${ }^{52} \mathrm{O}$ historiador está se referindo às ideias do médico Dilevino Lennio (1505-1568), autor de Della complessione del corpo humano. DELUMEAU, Jean. O pecado e o medo, op. cit., p. 340.
} 
a se perguntar se Deus existe", ou perturbadas pelo "excesso de meditação sobre os fins últimos e sobra a eternidade do inferno", podendo facilmente conduzir ao desespero e ao suicídio. ${ }^{53}$

A reflexão sobre a penitência enquanto um efeito positivo e "bom" da tristeza está presente na obra Tratado do amor de Deus [1616], também de Francisco de Sales, sendo que nela fica evidenciada a peculiaridade desta tristeza, própria dos pecadores no instante da penitência, razão pela qual poderia ser chamada de "desprazer ou sentimento de detestação do mal". ${ }^{44}$ Para Sales:

É claro que a tristeza da verdadeira penitência não deve tanto ser chamada de tristeza [...]; tristeza que jamais é enfadonha nem desgostosa; tristeza que não entorpece o espírito, mas o torna ativo, pronto e diligente; tristeza que não abate o coração, mas o levanta pela oração e esperança, e o faz chegar aos ímpetos do fervor de devoção; tristeza que, no auge de suas amarguras, traz sempre a doçura de uma incomparável consolação... 55

Note-se, portanto, a busca que Sales faz pelos aspectos positivos da tristeza sentida na penitência: uma tristeza que tornaria o espírito "ativo, pronto e diligente", levantando o coração "pela oração e esperança”, conduzindo-o "aos ímpetos do fervor de devoção" e trazendo "a doçura de uma incomparável consolação". Nesse sentido, Sales rogava "que o penitente se entristeça sempre, mas que sempre também se alegre na sua tristeza" ${ }^{56}$

Os aspectos negativos da tristeza traziam consigo inúmeros outros sentimentos semelhantes, uma vez que ela poderia ser "enfadonha", "desgostosa", motivo de "amarguras", entorpecimento e abatimento do coração. ${ }^{57}$ Os discursos médicos e filosóficos antigos, recuperados na Europa moderna, expressavam que "toda paixão supóe uma alteração da alma, assim como um movimento do coração (que se contrai ou expande) e uma troca do equilíbrio dos humores", ${ }^{58}$ sendo que a tristeza era associada ao frio e à contração dolorosa do coração, por engendrar emoçóes baseadas na dor. ${ }^{59} \mathrm{~A}$ tristeza podia, assim, conduzir à morte, ${ }^{60} \mathrm{O}$

\footnotetext{
${ }^{53}$ Ibidem, p. 349.

${ }^{54}$ A referência feita ao Tratado do amor de Deus encontra-se na obra de Tomás Kempis, publicada em 2011, pela Editora Vozes, que observa a edição de 1919 realizada pelo Revmo. Pe. Fleury, que procurou conjugar Kempis e Sales. Veja-se: KEMPIS, Tomás de. Imitação de Cristo: com reflexões e oraçôes de São Francisco de Sales. 2. ed. Petrópolis: Vozes, 2011, p. 69.

${ }^{55}$ Idem.

${ }^{56}$ SALES, Francisco de. Introdução à vida devota, op. cit., p. 69.

${ }^{57}$ Idem. O médico Thurneisser (1531-1596), da corte de Brandenburgo, faz referência a um homem que sofria tribulação do coração, de modo que se sentia frequentemente triste, e o diagnóstico indicava coração frio, sangue pouco quente, que provocaram ira, irritação e pensamentos melancólicos. Mas o coração se abatia também em função dos entristecimentos que chegavam com facilidade (RUBLACK, Ulinka. Flujos. El cuerpo y las emociones en la Edad Moderna, op. cit., p. 108).

${ }^{58}$ OROBITG, Christine. El sistema de las emociones, op. cit., p. 81. Tradução livre.

${ }^{59}$ Ibidem, p. 81, 83. Tradução livre.

${ }^{60}$ Essa ideia de que a tristeza podia matar atravessou o século XVIII em Portugal. Na publicação Medicina teológica [1794], o autor — médico Francisco de Melo Franco — apontava que "a tristeza podia ser fatal",
} 
que levava Sales a considerar, citando passagem bíblica ( $E c .25$ e 30), que ela matava a muitos e não era aproveitada por ninguém. ${ }^{61}$ Sendo uma paixão insalubre, a tristeza era mortífera, pois promovia o encolhimento, a opressão interior, o envenenamento do sangue. ${ }^{62}$ Em sua condição de o "menos nobre dos humores", a melancolia se associava à "velhice, à invalidez, às contrariedades, aos sofrimentos e à morte". ${ }^{3}$

Na primeira metade do século XVIII, o médico Francisco Henriquez publicou em Portugal, em 1721, a obra Âncora medicinal, na qual destacava, ao final, as "paixóes da alma" ou "paixóes do ânimo", dentre as quais figurava a tristeza. Para o médico português, formado em Coimbra,

A tristeza faz recolher ao interior do corpo o calor dele, o sangue e os espíritos, de que resulta o impedimento da transpiração insensível pela periferia do corpo, de que nascem febres humorais podres e outros muitos danos. E continuando a tristeza, debilita o calor natural, refrigera e desseca o corpo, faz pálida a cor do rosto e finalmente vem a consumir e gastar os espíritos e toda a valentia do corpo se vem a render à tirania da morte. ${ }^{64}$

Motivo de investidas dos inimigos, a tristeza era, para Sales, meio maldoso de produzir tentaçóes aos sujeitos "bons". Essas tentaçóes se relacionavam a atitudes que causavam alegria ${ }^{65}$ no pecado e entristeciam os bons diante da realização de suas "boas obras". Mas, acima de tudo, Sales alertava que o inimigo era triste e melancólico e "deseja que todos sejam como ele". ${ }^{66}$ A tristeza era, então, associada a um indivíduo, cuja conduta má, por ser con-

excetuando-se "aqueles que contavam com boa condição física". STEIN, Tarcila Nienow. Sobre ébrios, lascivos e coléricos: os corpos enfermos na obra de Francisco de Melo Franco (1794). Oficina do Historiador, Porto Alegre, PUC-RS, Suplemento Especial — IEPHIS/PUCRS, p. 949-962, 2014. p. 954.

${ }^{61}$ O padre jesuíta Antônio Vieira, no Sermão do Mandato (1643), ao lembrar o diálogo de despedida entre Cristo e seus discípulos, assinalava a dualidade tristeza/alegria: "O que neles é tristeza, para ser amor, havia de ser alegria: e o que em mim parece que havia de ser alegria, porque é amor, é tristeza.” VIEIRA, Antônio. Essencial Padre Antônio Vieira. Org. e introdução Alfredo Bosi. São Paulo: Companhia das Letras, 2011 [1643]. p. 361-362.

${ }^{62}$ OROBITG, Christine. El sistema de las emociones, op. cit., p. 84-86. Tradução livre.

${ }^{63}$ DELUMEAU, Jean. O pecado e o medo, op. cit., p. 327.

${ }^{64}$ HENRIQUEZ, Francisco da Fonseca. Âncora medicinal: para conservar a vida com saúde. Cotia: Ateliê Editorial, 2004 [1721]. p. 284.

${ }^{65}$ Nos séculos XVII e XVIII, os extremos dessas paixões contrárias (alegria e tristeza) podiam assumir reações físicas, tal como anunciava um provérbio: "O excesso de tristeza ri. O excesso de alegria chora" (POTKAY, Adam. A história da alegria, op. cit., p. 24). De modo similar, Descartes afirmou: "quando estamos extraordinariamente alegres, nunca o motivo dessa alegria faz que disparemos a rir; e mesmo não podemos tão facilmente ser incitados a isso por qualquer outra causa a não ser quando estamos tristes" (DESCARTES, René. As paixóes da alma, op. cit., p. 111). O padre Antônio Vieira, no Sermão da segunda dominga da quares$m a$, refletiu sobre o contraste tristeza/alegria, destacando que "não há alegria ou causa de alegria, tão contrária e alheia de toda a tristeza, que não dê que penar ao coraçáo"; "não há alegria neste mundo tão privilegiada que não pague pensão à tristeza”. Disponível em: http://www.literaturabrasileira.ufsc.br/documentos/?action=download\& id=37326. Acesso em: 20 set. 2017.

${ }^{66}$ SALES, Francisco de. Introdução à vida devota, op. cit., p. 457. 
tagiosa, poderia influenciar, modelar e conduzir o comportamento alheio. A ideia da ação contagiosa da melancolia também se fazia presente na linguagem médica do período, como bem apontado por Delumeau:

A melancolia é, portanto, [...] uma doença da regiáo abdominal onde se acumula a atrabile ${ }^{67} \mathrm{e}$ de onde escapam as exalaçôes tóxicas para o cérebro. Esses vapores saem às vezes pela boca do paciente e entấo se mostram contagiosos. Cita-se o caso de um alemão que fazia em casa suas devoçóes da Semana Santa porque temia a quantidade muito grande de "vapores de melancolia exalados pela multidão de fiéis contritos". ${ }^{68}$

Essa tristeza má, comparada à melancolia, era encarada como perturbadora, como aquele sentimento de perturbação da alma, causador de desassossego, desgostos, privaçôes, desalento, indecisão, opressão, entorpecimento e descontentamentos. Para Sales, era, portanto, um sentimento prejudicial à alma, ao cérebro e às forças e faculdades espirituais:

A tristeza má [...] causa temores desordenados, desgosto da oração, esfria e oprime o cérebro, priva a alma de conselho, de resolução, de juízo e coragem e lhe prostra as forças, em uma palavra, é como o rigoroso inverno, que consome toda a formosura da terra e entorpece todos os animais, porque priva a alma de toda a suavidade e a torna como tolhida e impossibilidade em todas as suas faculdades. ${ }^{69}$

A preocupação de Sales estava voltada para o estado da alma e a possibilidade de expansão das suas faculdades e força, o entusiasmo e ânimo que lhe eram considerados intrínsecos. Com efeito, a tristeza, metaforicamente, se apresentava como o inverno, o frio, o entorpecimento, a opressáo, a privaçáo e o tolhimento. Na teoria humoral, o temperamento melancólico corresponderia "à idade declinante e primeira velhice" e os melancólicos seriam indivíduos "tristes, desolados, fechados, severos e rudes, invejosos e tímidos" ${ }^{70}$

Na primeira metade do século XVIII, como se pode constatar no Vocabulário de Raphael Bluteau, tristeza continuou sendo definida como "doença incurável”, como o "maior inimigo da saúde". ${ }^{71}$ E, embora estejamos tomando — tal como Bluteau — melancolia e tristeza como sinônimos, alguns discursos médicos pareciam às vezes diferenciá-las — sendo que a tristeza era vista como um efeito do sujeito melancólico — como se observa em Tomás Mu-

\footnotetext{
${ }^{67}$ Atrabile pode ser definida como bile negra, que, na Antiguidade, acreditava-se ser produzida nas glândulas suprarrenais e responsável pela melancolia e pela hipocondria.

${ }^{68}$ DELUMEAU, Jean. O pecado e o medo, op. cit., p. 326.

${ }^{69}$ SALES, Francisco de. Introdução à vida devota, op. cit., p. 457.

${ }^{70}$ DELUMEAU, Jean. O pecado e o medo, op. cit., p. 325.

${ }^{71}$ BLUTEAU, Raphael. Supplemento ao Vocabulario portuguez, e latino. Parte II. Lisboa: Patriarcal Officina da Música, 1728. p. 390-391.
} 
rillo y Velarde: "o medo e a tristeza que sempre padecem os afligidos melancólicos". ${ }^{72}$ Como "uma herança da antiguidade", o "médico grego Hipócrates (460-377 a.C.) afirma[va] que quando o temor e a tristeza persistem um longo tempo, trata-se do estado melancólico". ${ }^{73} \mathrm{O}$ verbete "tristeza" de Bluteau vinha acompanhado de uma grande explanação. Inicialmente tomada como sinônimo de melancolia e hipocondria, a tristeza ganharia, em outros contextos, significados diversos. Encarada como "tesouro da vida", ela era vista também como capaz de tirar dos indivíduos "o uso do discurso", promovendo o isolamento ("obriga-nos a fugir da gente") e a solidão ("buscar a soledade").

Ao recomendar certos "remédios" para a tristeza, Sales parece demonstrar que, por sua difícil "cura", esse sentimento demandava tratamento. De acordo com Bluteau, a medicina fornecia remédios para as enfermidades corporais, mas para os "ataques do espírito", "nunca ou raras vezes" havia remédios, pois a "profunda tristeza" era comparada à "gota", o "opróbrio da medicina". ${ }^{74}$ Vejamos, então, quais os "remédios para a tristeza" indicados por Sales.

\section{Remédios para a tristeza}

Os remédios indicados para aqueles que fossem atingidos pela tristeza má consistiam em recomendaçôes baseadas na Bíblia. Como primeiro remédio, embasado no evangelho de São Tiago, Sales anunciava: Se alguém está triste, ore. A oração era, portanto, considerada o "remédio soberano" por elevar o espírito a Deus e a "única alegria e consolação" 75 Além disso, a oração (mental) era elemento predominante na Devotio moderna, desde o fim do período medieval, embora não fosse consenso entre os membros da Igreja Católica nos séculos XVI e XVIII. ${ }^{76}$

Assim como Sales, outros escritores religiosos, como Luís de Granada, "defenderam a prática da oraçáo mental" para a vida dos leigos, ensinando "o método de meditar nos

\footnotetext{
${ }^{72}$ VELLARDE, Aprobación de ingenios (Zaragoza, 1672), apud OROBITG, Christine. El sistema de las emociones, op. cit., p. 95.

73 SILVA, Paulo José Carvalho da. O tratamento da melancolia segundo Étienne Binet (1627). Filosofia e História da Biologia, v. 5, n. 1, p. 115-125, 2010. p. 116.

${ }^{74}$ O filósofo Juan Luís Vives (1492-1540), em Tratado del alma (1557), afirmava que "a melancolia acelera o envelhecimento e a morte" (apud OROBITG, Christine. El sistema de las emociones, op. cit., p. 96). Todavia, poderia estar vinculada ao estado hipocondríaco. Valendo-se das ideias do médico francês Ambroise Paré, Delumeau apontou que "a melancolia, como doença, pode ser provocada por fatores geradores de humor negro ou por um mau funcionamento de um dos órgãos abdominais cujo conjunto forma o 'hipocôndrio' - baço, fígado, vesícula, bexiga, útero, etc. Essa disfunção criaria, então, 'aquela espécie de loucura que nós chamamos muito bem melancolia hipocondríaca” (DELUMEAU, Jean. O pecado e o medo, op. cit., p. 325). ${ }^{75} \mathrm{Na}$ medicina, o tratamento da melancolia se dava através de purgativos e de evacuativos empregados para expelir o "humor espesso", "corrompido", "viscoso e negro", e, também, de confortativos utilizados para devolver "ao doente o vigor e a alegria" (DELUMEAU, Jean. O pecado e o medo, op. cit., p. 326).

${ }^{76}$ BORGES, Célia Maia. Livros de devoção e exercícios oracionais no Brasil Colônia, op. cit., p. 155.
} 
mistérios de Cristo e na vida interior e 'afectiva' da oração e da prática cristã" e declarando "que o homem mais facilmente eleva o seu coração a Deus se adotar a oraçáo mental". 77 A oração mental, elemento central no pensamento salesiano, era entendida como " prática familiar com a Divina Majestade', enquanto a meditação era percebida como 'primeiro grau da oração ou teologia mística'” ${ }^{78}$ Os escritos espirituais de Teresa d'Ávila — uma referência amplamente conhecida no período moderno - recomendavam a oraçáo e, "no Livro das fundaçôes consagra um capítulo inteiro à questáo de saber 'como as superioras devem tratar as religiosas melancólicas", 79 sendo que o sexo feminino era considerado de "especial fraqueza" e mais "propenso a melancolia e excesso de imaginação". ${ }^{80}$ Manuel Bernardes — outro religioso e escritor de diversas obras de referência em termos doutrinários e teológicos também elencou benefícios da oração mental nos Exercícios espirituais (1686). A oração

[...] reforma a vida, purga os pecados, ilumina os mistérios da fé, dá a graça do discernimento, endireita a intenção, traz desapego, consola nas tribulações, amedronta os demônios, tira as tristezas do coraçáo, facilita a mortificaçáo, gera paz de consciência, alcança favores de Deus e aproxima as pessoas. ${ }^{81}$

Para combater a tristeza, no entanto, náo bastava incentivar os sujeitos católicos a orarem, sendo necessário enfatizar o modo como deveria se dar a oração: "quando orardes, usai de afetos e palavras, sejam exteriores ou interiores, que se encaminhem à confiança e amor de Deus" ${ }^{82} \mathrm{Na}$ oração, para conquistar a confiança do divino, Sales apresenta exemplos de como o fiel/leitor deveria se dirigir a Deus: "oh Deus de misericórdia! Meu bom Deus! Meu benigno salvador! Deus do meu coração! Alegria minha! Minha esperança! Meu amado esposo! Bem-amado da minha alma!" ${ }^{83}$ A oração promoveria, então, a alegria, que por ser efeito contrário à tristeza, conduziria à expansão e ao conforto do coraçãoo. ${ }^{84}$

O segundo remédio era o de resistir "vivamente" às inclinaçóes da tristeza. Nesse sentido, por exemplo, Tomás de Kempis já aconselhava os fiéis/leitores a não esperarem favores de outros, ao recomendar: "não te entristeça a falta dos humanos favores". ${ }^{85}$ Essa resistência à tristeza estava presente, também, na obra Alivio de tristes — publicada em Portugal entre

\footnotetext{
${ }^{77}$ Ibidem, p. 156.

${ }^{78}$ Ibidem, p. 161.

${ }^{79}$ DELUMEAU, Jean. O pecado e o medo, op. cit., p. 321.

80 TAVARES, Pedro Vilas Boas. Beatas, inquisidores e teólogos. Reacção portuguesa a Miguel de Molinos.

Dissertação (Doutoramento em Cultura Portuguesa) — Universidade do Porto, 2002. p. 189.

${ }^{81}$ SARTIN, Philippe Delfino. A tentação e a contemplação. Manuel Bernardes (1644-1710) e o Oratório de

Lisboa. Dissertação (Mestrado em História) - UFG, Goiânia, 2013. p. 197.

${ }^{82}$ SALES, Francisco de. Introdução à vida devota, op. cit., p. 457.

${ }^{83}$ Ibidem, p. 458.

${ }^{84}$ OROBITG, Christine. El sistema de las emociones, op. cit., p. 84.

${ }^{85}$ KEMPIS, Tomás de. Imitaçâo de Cristo, op. cit., p. 68.
} 
o XVII e o XVIII — na qual seu autor, Mateus Ribeiro, a vincula à certeza do consolo, do alívio e da tranquilidade promovidas pelo poder divino:

Meu intento é aproveitar com este pequeno volume a todos os que no mar deste mundo navegam derrotados de sentimentos, molestados de tristezas, queixando-se continuamente das que se chamam erradamente desgraças e infortúnios. O maior prêmio para mim deste trabalho será que todos com ele suas afliçóes aliviem e suas queixas consolem, [...] encaminhando aos queixosos para que não desanimem com as tormentas desta peregrinação. ${ }^{86}$

As boas obras eram uma forma eficaz de combate da aflição causada pelo inimigo, geralmente, um poder demoníaco, já que os teólogos estavam “inclinados a perceber a ação do demônio que tenta mergulhar as almas piedosas numa tristeza que as desviaria do sérvio divino". ${ }^{87}$ Portanto, resistir nas boas obras era fundamental:

[...] ainda que vos pareça que tudo o que neste tempo fizerdes, o fazeis com frieza, tristeza e frouxidão, nem por isso deixeis de o fazer, porque o inimigo, que pretende entibiar-nos nas boas obras, com a tristeza, vendo que não deixamos de as fazer e que sendo feitas com resistência são de maior valor, cessará de nos afligir. ${ }^{88}$

Outro remédio indicado por Sales para que o fiel espantasse a tristeza era o canto, como se constata nesta passagem: "Cantai cânticos espirituais, porque o inimigo muitas vezes por este meio desiste da sua obra." ${ }^{89}$ É plausível supor que essa importância que a música religiosa possuía para a eliminação da tristeza estivesse, muito provavelmente, inspirada em Santo Agostinho. Em Confissóes, ele refletiu sobre "O prazer do ouvido" relatando que encontrava "algum descanso nos cânticos que as vossas palavras vivificam, quando são entoadas com suavidade e arte”. ${ }^{90}$ No século XVIII, o teólogo espanhol Tomás Vicente Tosca (1651-1723), ao teorizar sobre os efeitos da audição musical, afirmou que cantando se movem fibras no cérebro que causam alegria, dispersando os espíritos tristes e melancólicos. ${ }^{91}$

A música, em geral, também se fazia presente entre os diversificados meios de ação sobre o psiquismo e de cura da melancolia anunciados pela literatura médica: "boa divisão do trabalho e do repouso, do sono e da vigília, recurso à música, ao vinho branco suave, às cores

\footnotetext{
${ }^{86}$ SANTOS, Zulmira. Vícios, virtudes e paixôes, op. cit., p. 192.

${ }^{87}$ DELUMEAU, Jean. O pecado e o medo, op. cit., p. 326-327.

${ }^{88}$ SALES, Francisco de. Introdução à vida devota, op. cit., p. 458.

${ }^{89}$ Idem.

${ }^{90}$ AGOSTINHO, Santo. Confissóes. Trad. J. Oliveira e Ambrósio de Pina. Petrópolis: Vozes, 2011. p. 247. (Livro X, cap. 33.)

${ }^{91}$ VIRUMBRALES, Luis Lozano. De efectos y afectos en la música. In: TAUSIET, María; AMELANG, James

S. (Orgs). Accidentes del alma: las emociones en la Edad Moderna. Madrid: Abada Editores, 2009. p. 312.
} 
agradáveis [...], aos contos cômicos, às companhias alegres que evitarão a solidão..." ${ }^{2}$ Também entre médicos luteranos, o recurso à oração e ao canto parecem ter sido considerados eficazes. Dentre eles, Rublack ${ }^{93}$ destaca o médico da corte de Wittenberg, Rosnius Lentilius, que, no final do século XVII, recebeu uma carta de um pastor, que relatava a situação de sofrimento de uma mulher melancólica e sua crença de que o equilíbrio das emoções poderia ser restaurado por meio de oraçôes e cantos. Os próprios médicos atribuíam importância às práticas devocionais, na medida em que o canto era uma maneira de contar a Deus os temores e problemas cotidianos, com a esperança de receber ânimo e misericórdia.

Ocupar-se das "obras exteriores" também era um remédio indicado para o combate da frieza que acompanhava o estado do espírito triste: "É também bom empregarmo-nos em obras exteriores e variá-las o mais que possível for, para divertir a alma do objeto triste, e assim também purificar e aquecer os espíritos, porque a tristeza é uma paixão de compleixão [sic] fria”. ${ }^{4}$ A assertiva de Sales estava, como já destacamos, muito próxima da teoria humoral, pois a melancolia era percebida como um humor "denso, frio, seco e ácido", de modo que o sujeito melancólico era encarado geralmente como "triste e pensativo". 95 Segundo Delumeau, ${ }^{96}$ até o século XVIII, "considerou-se que uma tristeza prolongada provinha de um humor corrompido", devido a um desequilíbrio do humor da melancolia (a "bile negra") no sangue. Então, a sugestão de Sales era a dedicação a variadas "obras exteriores" — tais como a caridade, a penitência, a oração. De modo similar, Robert Burton ${ }^{97}$ indicava, especialmente para as mulheres, uma série de ocupaçóes e tarefas domésticas que poderiam tornar sua vida agradável — e menos ociosa —, como "o bordado, as geleias, a faxina, a jardinagem, os mexericos" ${ }^{98}$ Já as idosas, segundo ele, “cuja natureza melancólica levaria à ociosidade", poderiam, com seus terços, dizer muitos Pater noster, Ave Maria, Credo". 99

Também o fervor religioso era tido como um remédio para a tristeza, através, especialmente, da mediação do crucifixo:

\footnotetext{
${ }^{92}$ DELUMEAU, Jean. O pecado e o medo, op. cit., p. 327.

${ }^{93}$ RUBLACK, Ulinka. Flujos. El cuerpo y las emociones en la Edad Moderna, op. cit., p. 118-119.

${ }^{94}$ SALES, Francisco de. Introdução à vida devota, op. cit., p. 458.

${ }^{95}$ OROBITG, Christine. El sistema de las emociones, op. cit., p. 72.

${ }^{96}$ DELUMEAU, Jean. O pecado e o medo, op. cit., p. 322.

${ }^{97} \mathrm{O}$ erudito inglês Robert Burton (1577-1640) estudou e ensinou em Oxford, além de ter atuado como vigário na igreja de St. Thomas. Sua obra Anatomia da melancolia é considerada um clássico da prosa em língua inglesa, constituindo-se em estudo filosófico, médico e histórico sobre a natureza da melancolia. Se, de acordo com a teoria dos quatro humores, a melancolia era causada pelo excesso de bílis negra, para o clérigo anglicano e acadêmico Burton, a melancolia era consequência do pecado original, que afastava o homem de Deus. A obra, que, originalmente, foi publicada em 1621, teve cinco revisôes feitas pelo próprio autor até 1638 .

${ }^{98}$ MINOIS, Georges. A Idade de Ouro. História da busca da felicidade. Trad. Christiane Fonseca Gradvohl Colas. São Paulo: Unesp, 2011. p. 193.

${ }^{99}$ BURTON apud MINOIS, Idem.
} 
Executai açóes externas fervorosas, ainda que seja sem gosto, abraçando a imagem do crucifixo, apertando-a ao peito, beijando-lhe os pés e as mãos, e levantando as mãos e olhos ao Céu, a Deus, com palavras de amor e confiança, como são estas: Meu amado, para mim, e eu para ele. Meu amado é para mim um ramalhete de mirra, que se deterá entre meu coração (Cant. 2,16). Meus olhos desfalecem em vós, oh meu Deus, dizendo quando me consolareis vós? (Ps. 118, 82). Jesus, sede para mim Jesus, viva Jesus e viverá a minha alma: Quem me apartará do amor de meu Deus? [...] e outros semelhantes. ${ }^{100}$

Essa relação afetiva do devoto com o crucifixo era bastante recomendada também por outros religiosos. No século XVIII, o dominicano português João Franco, na obra Mestre da virtude [1745], apontava para a importância do "Cristo crucificado, com o qual se consola nas suas tristezas", assinalando que "não pode ter tristezas quem se chega a Cristo crucificado". Para a oração dirigida, a recomendação de Franco era: "Dize-lhe a tristeza que padeces, nascida dos teus pecados. Dize-lhe a confusão em que te deixou a tua culpa, [...] os temores que te assombram, e as angústias que te cercam". ${ }^{101} \mathrm{O}$ manuseio e a utilização do crucifixo em momentos diversos da vida cotidiana dos católicos — em oraçóes, confissóes, missas, coros e nas próprias vestimentas - constituía-se em exteriorização da vida religiosa exemplar, e, no caso de mulheres religiosas conventuais ou recolhidas, podia significar ou reforçar atributos de santidade. ${ }^{102}$ As açóes fervorosas indicadas por Sales poderiam ser comparadas à beatitude, enquanto contentamento de espírito como proposto por Descartes, uma vez que "viver em beatitude, nada mais é do que ter o espírito perfeitamente contente e satisfeito". ${ }^{103}$

Outro remédio considerado "bom" contra a tristeza era a "disciplina moderada", "porque esta voluntária aflição exterior impetra a consolação interior, e a alma, sentindo as dores de fora, se esquece das que tem dentro. A frequência da Sagrada Comunhão é excelente porque este pão celeste fortifica o coração e alegra o espírito" ${ }^{104}$ A comunhão preparava e antecedia a confissão e, para os "homens da Igreja”, a "recusa da confissão" seria "uma recusa de Deus", a "consequência mais dramática da melancolia". ${ }^{105}$

Se a "disciplina moderada" e as "dores de fora” eram bons remédios, Sales provavelmente estava fazendo referências a disciplinas e cilícios comumente realizados por mulheres, especialmente conventuais. No caso da vida monástica feminina em Portugal, as religiosas aplicavam-se moderados e rigorosos flagelos como "cilícios de ferro pelo corpo", "uso de rou-

\footnotetext{
${ }^{100}$ SALES, Francisco de. Introdução à vida devota, op. cit., p. 459.

${ }^{101}$ FRANCO, Fr. João. Mestre da Virtude, segunda parte do Mestre da Vida, que persuade a todas as criaturas de qualquer estado que sejam, o que é necessário para se salvarem, e o que hão de fazer para serem santos. Lisboa: Oficina dos herd. de Antonio Pedrozo Galvão, 1745. p. 424.

${ }^{102}$ Entretanto, "jejuns abusivos", "solidão prolongada" e "reflexôes exaustivas sobre o além" poderiam levar à melancolia, ao desespero e "à vertigem fatal” (DELUMEAU, Jean. O pecado e o medo, op. cit., p. 349).

${ }^{103}$ DESCARTES, 1645 apud MINOIS, Georges. A Idade de Ouro, op. cit., p. 199.

${ }^{104}$ SALES, Francisco de. Introdução à vida devota, op. cit., p. 459.

${ }^{105}$ DELUMEAU, Jean. O pecado e o medo, op. cit., p. 348.
} 
pas de tecido áspero", "tábua como cama”, ferimentos no "peito com um canivete", aplicação de urtigas na pele e ainda jejuns e abstinências. ${ }^{106}$

Além da indicação desses remédios, Francisco de Sales faz ainda inúmeras "sugestôes” aos que sofriam de tristeza:

Descobrireis todos os ressentimentos, afetos e sugestóes, que provieram da vossa tristeza, ao vosso diretor e confessor, humilde e fielmente. Buscai a conversação de pessoas espirituais, frequentando-as o mais que puderdes nesse tempo. Finalmente, resignai-vos nas mãos de Deus, dispondo-vos a sofrer esta tristeza enfadonha com paciência, como justo castigo das vossas alegrias vãs. ${ }^{107}$

A conversa com "pessoas espirituais", a resignação, a paciência e a confiança em Deus eram, portanto, considerados meios eficazes para a superação do "mal” da tristeza. Tomás de Kempis já destacava a necessidade de o cristão não se entregar "à vã alegria”, devendo, ao contrário, refrear os sentidos com a disciplina, conservando o temor de Deus, pois o homem não poderia "nesta vida, gozar perfeita alegria". ${ }^{108}$

Se a tristeza havia de ser superada com a aplicação de distintos e complementares "remédios", a máxima "Nos dias felizes lembra-te da desgraça"109 não deveria ser esquecida. O sofrimento de tristeza - que atingiria diretamente o coração — deveria ser paciente e resignado, confiante na providência divina, encarado como passageiro e com duração específica ("nesse tempo" [de tristeza]), para que o coração fosse fortalecido, fortificado e levantado.

\section{Considerações finais}

Na obra Introdução à vida devota, que foi amplamente publicada entre os séculos XVII e XVIII em Portugal, a tristeza apresentava sentido e sintomas particulares, mas com relativa sintonia com as concepçóes filosóficas e as teorias médicas da época. Contra ela, eram recomendados remédios espirituais, como nas instruçóes de Sales; os consolos, de acordo com as obras literárias, ou, então, os tratamentos do corpo, fundamentados na teoria humoral, que podiam ser encontrados nos tratados médicos.

No século XVII, a melancolia e a ideia da cólera divina parecem, segundo Minois, ${ }^{110}$ dominar o pensamento de crentes e descrentes. Nesse período, predomina o pessimismo

\footnotetext{
${ }^{106}$ BELLINI, Lígia; PACHECO, Moreno Laborda. Experiência e ideais de vida religiosa em mosteiros portugueses clarianos, nos séculos XVII e XVIII. Revista de História, n. 160, p. 147-167, 2009. p. 158.

107 SALES, Francisco de. Introdução à vida devota, op. cit., p. 459-460.

${ }^{108}$ KEMPIS, Tomás de. Imitação de Cristo, op. cit., p. 67.

${ }^{109}$ SALES, Francisco de. Introdução à vida devota, op. cit., p. 487.

${ }^{110}$ MINOIS, Georges. A Idade de Ouro, op. cit., p. 189-190.
} 
em relação à ideia de felicidade, mesmo entre os pensadores mais racionais. Foi, por exemplo, em 1621 que Robert Burton publicou a monumental Anatomia da melancolia, na qual expressava: "A vida é fastidiosa e dura mesmo para quem a vive melhor; é uma tristeza de nascer, uma dor de viver, uma pena de morrer [...] pois não existe prazer aqui no mundo ao qual não esteja misturado um pouco de tristeza; [...] Para tão ínfima quantidade de alegria, quanta tristeza; após tão pouco prazer, tão grande miséria!". ${ }^{111}$ Também o humanismo devoto de Sales "considera a tristeza um estado perigoso que pode levar ao desespero. Mas sua posição é delicada: de um lado, a consciência de nosso pecado nos impede de sermos felizes; de outro, devemos confiar; o meio-termo é uma 'modesta alegria e animação". ${ }^{112}$

Francisco de Sales propunha exames de consciência, de maneira que o sujeito pudesse conhecer o "estado [em que] se acha o nosso coração" e o "conhecimento das próprias paixôes", como, por exemplo, para constatar se "na tristeza" o comportamento é "muito" excessivo "por coisas vãs". ${ }^{113}$ A própria obra - Introdução à vida devota — teria, em última instância, sido produzida por Sales para animar a devoção em uma alma triste. Segundo Ana Costa, o livro foi composto

[...] em grande parte pelas cartas de direção espiritual escritas à senhora de Charmoisy, [...] após o casamento com Claude de Charmoisy, oriundo da Saboia e parente de S. Francisco de Sales, [que] viu-se retirada para um castelo solitário e privada da companhia do marido, constantemente ausente devido a funçóes diplomáticas. Mergulhada numa enorme tristeza vê a sua vida transformada pelo Santo, que lhe revela o segredo de uma vida bela: animar os mais simples deveres quotidianos com o amor de Deus. Ela encontraria nesse amor de que lhe fala o Santo a força que lhe havia de ser ainda mais necessária quando ficou viúva e tomou a direção da sua casa. ${ }^{114}$

Livros religiosos e de conforto diante de tristezas parecem ter sido muito apreciados pelo público leitor e devoto, notadamente entre as mulheres, em Portugal. José Carvalho destacou o caso do nobre português e grande bibliófilo Vicente Nogueira, encarregado por d. Vasco Luis da Gama, embaixador português em Paris, de adquirir livros para sua biblioteca e de fazer uma lista de livros que poderiam interessar à marquesa de Niza - $\mathrm{d}$. Inês de Noronha, esposa de Gama. Entre esses livros estavam os cinco tomos de Spelho de consolação dos tristes. O marquês teria agradecido e acrescentado: "Os livros que V. M. me aponta determina nomear para a licença da marquesa me parece são os com que ela se contentará [...] porquanto não lê mais que os de Meditaçóes, e vidas de santos e cousas devotas, oraçóes,

\footnotetext{
${ }^{111}$ Ibidem, p. 191.

${ }^{112}$ Ibidem, p. 177.

113 SALES, Francisco de. Introdução à vida devota, op. cit., p. 507.

${ }^{114}$ COSTA, Ana. S. Francisco de Sales, diretor espiritual. Via Spiritus, v. 22, p. 5-29, 2015. p. 9. Grifo nosso.
} 
ofícios, evangelhos, epistolas". ${ }^{115}$ Assim, obras religiosas como Introdução à vida devota, além de promoverem o incremento da vida piedosa, propunham-se, também, a curar ou minimizar os efeitos de sentimentos como a tristeza. Segundo Ana Costa, “o método seguido por S. Francisco de Sales incute nas almas dirigidas o otimismo, pois reconhece que a melancolia e o pessimismo são prejudiciais à alma”. ${ }^{116}$

Obras como a de Sales, voltadas ao público religioso leigo, ganhavam destaque em contextos paroquiais e em âmbitos escolares portugueses. Tal foi o caso do texto catequético de Marcos Jorge, Doutrina christã [1655], que se propunha a ser "formulação prática dos conteúdos doutrinais que facilitasse a sua apropriação por quem era instruído através deste tipo de texto" ${ }^{117}$ Assim, os exercícios de doutrinação recorriam "à memorização dos preceitos e à execução cotidiana de determinadas devoçóes", tal como se percebe em um dos versos das formas cantadas que o livro ensinava: "Examina cada dia,/ Tua alma com diligência,/ Terás paz \& alegria/ Que dá a boa consciência”. ${ }^{118}$ Constata-se que certas formas de difusão de práticas religiosas, tais como o exame de consciência, também promoveriam a conquista da alegria, o contrário da indesejada tristeza.

Embora Sales não mencione diretamente a teoria humoral ou refira autoridades médicas clássicas, as suas instruções parecem ser tributárias dos princípios hipocrático-galênicos vigentes no período, ${ }^{119}$ tal como se pode perceber na já referida passagem na qual afirma que "a tristeza é uma paixão de compleixão [sic] fria”. ${ }^{120}$ Sales, então, apenas tangenciava a explicação médica do mal da melancolia, cujo diagnóstico até o século XVIII implicava — para a ciência médica — uma certeza absoluta: o humor corrompido. ${ }^{121}$

De todo modo, a tônica da narrativa de Francisco de Sales não foi o combate à tristeza, sendo esta apenas um dos efeitos das tentaçóes a que os fiéis estavam sujeitos no mundo. Ao buscar inspirar a vida devota à filoteia, Sales concluía os seus Avisos sobre a tristeza, incentivando a fé cristã, a confiança no poder divino e o caráter efêmero do sofrimento melancólico: "tende por certo que Deus, depois que vos tiver experimentado, vos há de livrar deste mal". ${ }^{22}$

\footnotetext{
${ }^{115}$ CARVALHO, José Adriano de Freitas. Lectura espiritual en la peninsula ibérica (siglos XVI-XVII), op. cit., p. 47-48.

${ }^{116}$ COSTA, Ana. S. Francisco de Sales, diretor espiritual, op. cit., p. 06.

${ }^{117}$ PALOMO, Federico. A Contra-Reforma em Portugal, op. cit., p. 71.

${ }^{118}$ Ibidem, p. 73.

${ }^{119}$ Segundo Silva, "os tratados espirituais referiam-se a melancólicos torturados por afliçóes interiores, supostamente causadas pelo excesso de bile negra. Muitos, por sua vez, identificavam melancolia e tristeza, tratando-a como um mal essencialmente moral. Outros ainda conjugavam categorias humorais e das doutrinas sobre os afetos, [...] sem, contudo, compactuar com a hipótese da soberania do temperamento do corpo (predominância de um humor) na determinação do caráter moral”. SILVA, Paulo José Carvalho da. O tratamento da melancolia segundo Étienne Binet (1627), op. cit., p. 117-118.

${ }^{120}$ SALES, Francisco de. Introdução à vida devota, op. cit., p. 458.

${ }^{121}$ STAROBINSKI, Jean. A tinta da melancolia, op. cit., p. 130.

122 SALES, Francisco de. Introdução à vida devota, op. cit., p. 460.
} 


\section{Referências}

AGOSTINHO, Santo. Confissóes. Trad. J. Oliveira e Ambrósio de Pina. Petrópolis: Vozes, 2011.

ARAÚJO, Ana Cristina. A morte em Lisboa: atitudes e representaçóes, 1700-1830. Lisboa: Editorial Notícias, 1997.

BARTRA, Roger. Cultura y melancolia. Las enfermidades del alma en la España del Siglo de Oro. Barcelona: Anagrama, 2001.

BELLINI, Lígia; PACHECO, Moreno Laborda. Experiência e ideais de vida religiosa em mosteiros portugueses clarianos, nos séculos XVII e XVIII. Revista de História, n. 160, p. $147-167,2009$.

BLUTEAU, Raphael. Supplemento ao Vocabulario portuguez, e latino. Parte II. Lisboa: Patriarcal Officina da Música, 1728.

BORGES, Célia Maia. Livros de devoção e exercícios oracionais no Brasil Colônia: a biblioteca das Carmelitas Descalças no Rio de Janeiro. Séc. XVIII. In: FLECK, Eliane Cristina Deckmann; DILLMANN, Mauro (Orgs.). Escritas e leituras: temas, fontes e objetos na Iberoamérica, séculos XVI-XIX. São Leopoldo: Oikos; Unisinos, 2017, p. 145-172.

CARDOSO, António Barros. Livrarias e bibliotecas na Europa dos tempos modernos. The Overarching Issues of the Europen Space. Ed. Faculdade de Letras da Universidade do Porto, p. 361-373, 2013.

CARVALHO, José Adriano de Freitas. Lectura espiritual en la península ibérica (siglos XVI$X V I I)$ : programas, recomendaciones, lectores, tiempos y lugares. Salamanca: Editorial Semyr, 2007.

CARVALHO, José Adriano de Freitas. Do recomendado ao lido. Direcção espiritual e prática de leitura entre franciscanas e clarissas em Portugal no século XVII. Via Spiritus, 4, p. 7-56, 1997.

CARVALHO, José Adriano de Freitas (Dir.). Bibliografia cronológica da literatura de espiritualidade em Portugal. 1501-1700. Faculdade de Letras Universidade do Porto. Porto: Instituto de Cultura Portuguesa, 1988.

CHARTIER, Roger (Dir.). Práticas da leitura. Trad. Cristiane Nascimento. 5. ed. São Paulo: Estação Liberdade, 2011.

CHARTIER, Roger. As práticas da escrita. In: CHARTIER, Roger (Org.). História da vida privada, 3: da Renascença ao Século das Luzes. Trad. Hildegard Feist. São Paulo: Companhia das Letras, 2009. p. 113-162.

CHARTIER, Roger. Inscrever e apagar: cultura escrita e literatura, séculos XI-XVIII. Trad. 
Luzmara Ferreira. São Paulo: Unesp, 2007.

CHARTIER, Roger. Leituras e leitores na França do Antigo Regime. Trad. Álvaro Lorencini. São Paulo: Unesp, 2004.

COSTA, Ana. S. Francisco de Sales, diretor espiritual. Via Spiritus, v. 22, p. 5-29, 2015.

COSTA, Manuel Afonso. A ideia de felicidade em Portugal no século XVIII, entre as luzes e o romantismo. Eticidade, moralidade e transcendência. Tese (Doutorado em História e Teoria das Ideias) — Universidade Nova de Lisboa, 2008.

DAWSON, Christopher. A divisão da cristandade. Da Reforma Protestante à Era do Iluminismo. Trad. Márcia de Brito. São Paulo: É Realizações, 2014.

DELUMEAU, Jean. O pecado e o medo. A culpabilização no Ocidente (séculos 13-18). Trad. Álvaro Lorencini. Bauru: Edusc, 2003. v. 1.

DESCARTES, René. As paixóes da alma. Introdução, notas, bibliografia e cronologia por Pascale D’Arcy. Trad. Rosemary Costhek Abílio. 2. ed. São Paulo: Martins Fontes, 2005 [1649].

FIANCO, Francisco. O cavaleiro, a morte e o diabo: imanência, finitude e negatividade no pensamento barroco. In: OLIVEIRA, Cínthia Roso et al. (Orgs.). Filosofias da morte. Passo Fundo: Méritos, 2011. p. 73-100.

FRANCO, Fr. João. Mestre da Virtude, segunda parte do Mestre da Vida, que persuade a todas as criaturas de qualquer estado que sejam, o que é necessário para se salvarem, e o que hão de fazer para serem santos. Lisboa: Oficina dos herd. de Antonio Pedrozo Galvão, 1745. p. 424. HENRIQUEZ, Francisco da Fonseca. Ancora medicinal: para conservar a vida com saúde. Cotia: Ateliê Editorial, 2004.

KEMPIS, Tomás de. Imitação de Cristo: com reflexóes e oraçóes de São Francisco de Sales. Tradução das reflexões de Sales por Lúcia M. Endlich Orth. 2. ed. Petrópolis: Vozes, 2011. KLIBANSKY, Raymond; PANOFSKY, Erwin; SAXL, Fritz. Saturno y la melancolía. Madrid: Alianza Editorial, 2004.

LEBRUN, François. As reformas: devoções comunitárias e piedade pessoal. In: CHARTIER, Roger (Org.). História da vida privada, 3: da Renascença ao Século das Luzes. Trad. Hildegard Feist. São Paulo: Companhia das Letras, 2009. p. 76-112.

MARQUES, João Francisco. Oração e devoçôes. In: AZEVEDO, Carlos Moreira (Dir.). História da vida religiosa de Portugal. Humanismos e reformas. Lisboa: Círculo de Leitores, 2000, p. 603-675. v. 2.

MINOIS, Georges. A Idade de Ouro. História da busca da felicidade. Trad. Christiane Fonseca Gradvohl Colas. São Paulo: Unesp, 2011.

OROBITG, Christine. El sistema de las emociones: la melancolía en el Siglo de Oro Español. In: TAUSIET, María; AMELANG, James S. (Orgs.). Accidentes del alma: las emociones en 
la Edad Moderna. Madrid: Abada Editores, 2009. p. 71-98.

PALOMO, Federico. A Contra-Reforma em Portugal, 1540-1700. Lisboa: Livros Horizonte, 2006.

POTKAY, Adam. A história da alegria. Da Bíblia ao Romantismo tardio. São Paulo: Globo, 2010.

RUBLACK, Ulinka. Flujos. El cuerpo y las emociones en la Edad Moderna. In: TAUSIET, María; AMELANG, James S. (Orgs.). Accidentes del alma: las emociones en la Edad Moderna. Madrid: Abada Editores, 2009. p. 123-142.

SALES, Francisco de. Introdução à vida devota. Nova ediçáo revista e prefaciada com prólogo do padre Gonçalo Alves. Porto: Livraria Catholica Portuense, Centro de Propaganda religiosa em Portugal e Brazil, s/d [1609].

SANTOS, Zulmira. Vícios, virtudes e paixōes: da novela como "catecismo" no século XVIII. Revista de Estudos Ibéricos, Porto, n. 3, p. 187-199, 2006.

SARTIN, Philippe Delfino. A tentação e a contemplação. Manuel Bernardes (1644-1710) e o Oratório de Lisboa. Dissertação (Mestrado em História) — UFG, Goiânia, 2013.

SILVA, Paulo José Carvalho da. O tratamento da melancolia segundo Étienne Binet (1627). Filosofia e História da Biologia, v. 5, n. 1, p. 115-125, 2010.

STAROBINSKI, Jean. A tinta da melancolia. Uma história cultural da tristeza. Trad. Rosa Freire D’Aguiar. São Paulo: Companhia das Letras, 2016.

STEIN, Tarcila Nienow. Sobre ébrios, lascivos e coléricos: os corpos enfermos na obra de Francisco de Melo Franco (1794). Oficina do Historiador, Porto Alegre, PUCRS, Suplemento Especial — IEPHIS/PUCRS, p. 949-962, 2014.

TAVARES, Pedro Vilas Boas. Beatas, inquisidores e teólogos. Reacção portuguesa a Miguel de Molinos. Dissertação (Doutorado em Cultura Portuguesa) — Universidade do Porto, 2002. VIEIRA, Antônio. Essencial padre Antônio Vieira. Org. e introdução Alfredo Bosi. São Paulo: Companhia das Letras, 2011.

VIRUMBRALES, Luis Lozano. De efectos y afectos en la música. In: TAUSIET, María; AMELANG, James S. (Orgs.). Accidentes del alma: las emociones en la Edad Moderna. Madrid: Abada Editores, 2009. p. 307-344. 